\title{
The mechanisms of complement activation in normal bovine serum and normal horse serum against Yersinia enterocolitica 0:9 strains with different outer membrane proteins content
}

\author{
K. Miętka' ${ }^{1}$ K. Brzostek², K. Guz-Regner ${ }^{1}$, G. Bugla-Płoskońska ${ }^{1}$ \\ ${ }^{1}$ University of Wroclaw, Faculty of Biological Sciences, Institute of Genetics and Microbiology, \\ Department of Microbiology, S. Przybyszewskiego 63-77, 51-148 Wroclaw, Poland \\ ${ }^{2}$ University of Warsaw, Faculty of Biology, Institute of Microbiology, \\ Department of Applied Microbiology, I. Miecznikowa 1, 02-096, Warsaw, Poland
}

\begin{abstract}
Yersinia enterocolitica is a common zoonotic pathogen and facultative intracellular bacterium which can survive within blood cells. Cattle and horses are considered a reservoir of $Y$. enterocolitica which often causes several serious syndromes associated with yersiniosis such as abortions, premature births or infertility. The aim of our investigation was to determine the vitality of $Y$. enterocolitica O:9 strains (Ye9) in bovine and horse sera (NBS and NHrS) and explain the role of outer membrane proteins (OMPs) in serum resistance of these bacteria. Our previous studies demonstrated moderate human serum (NHS) resistance of the wild type Ye9 strain, whereas mutants lacking YadA, Ail or OmpC remained sensitive to the bactericidal activity of NHS. The present study showed that the wild type of Ye9 strain was resistant to the bactericidal activity of both NHrS and NBS, while Ye9 mutants lacking the YadA, Ail and OmpC proteins were sensitive to NHrS and NBS as well as to NHS. The mechanisms of complement activation against Ye9 strains lacking Ail and YadA were distinguished, i.e. activation of the classical/lectin pathways decisive in the bactericidal mechanism of complement activation of NBS, parallel activation of the classical/lectin and alternative pathways of NHrS. In this research the mechanism of independent activation of the classical/lectin or the alternative pathway of NBS and $\mathrm{NHrS}$ against Ye9 lacking OmpC porin was also established. The results indicate that serum resistance of Ye9 is multifactorial, in which extracellular structures, i.e. outer membrane proteins (OMPs) such as Ail, OmpC or YadA, play the main role.
\end{abstract}

Key words: Yersinia enterocolitica, serum resistance, normal bovine serum, normal horse serum, YadA, Ail, OmpC 


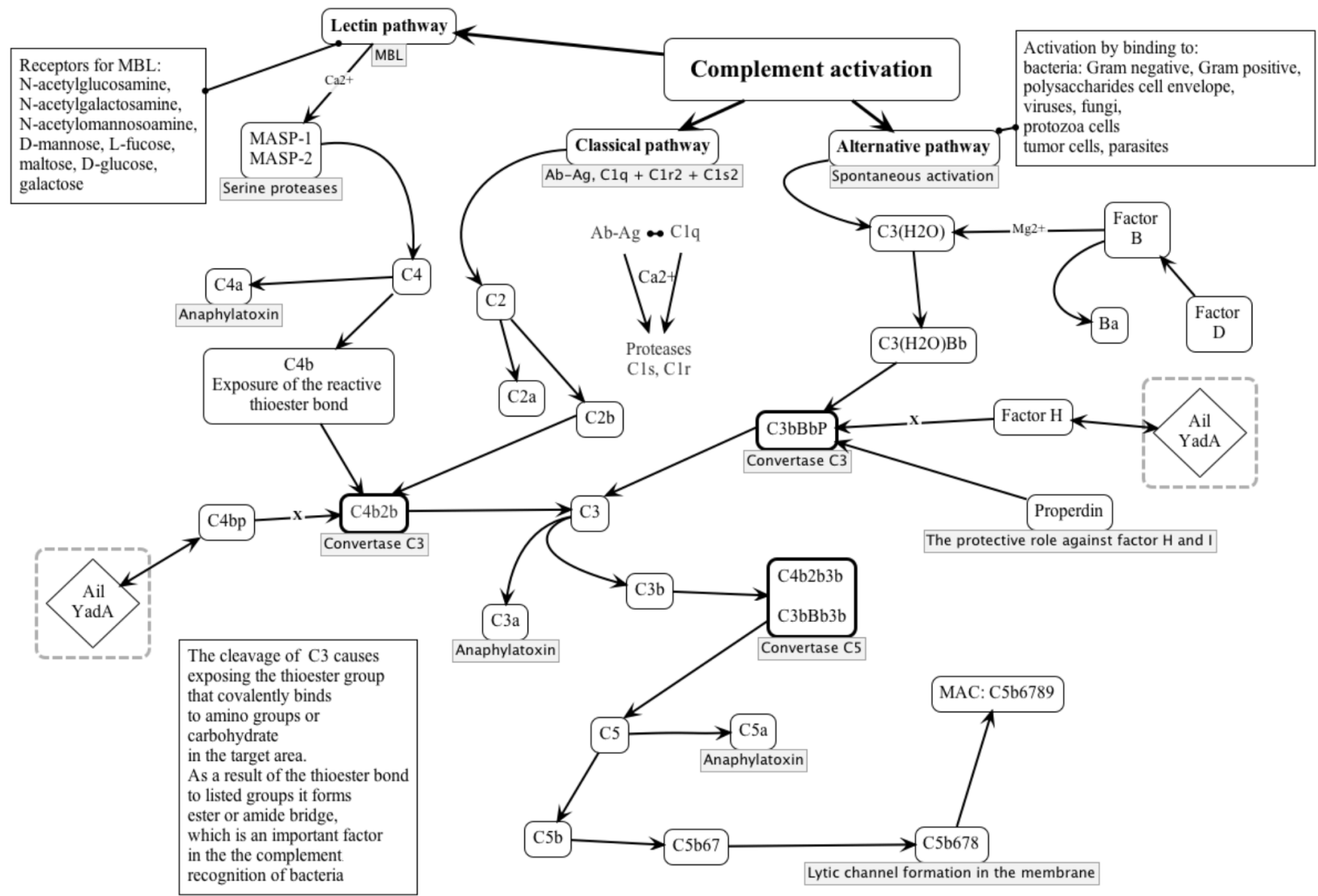

Fig. 1. Mechanisms of complement activation: YadA and Ail regulate the complement activation by affecting factor $\mathrm{H}$ and $\mathrm{C} 4 \mathrm{bp}$. Ab-Ag- an immune complex; C3(H2O)- spontaneously hydrolyzed form of C3 subunit, $\mathbf{C 3 ( H 2 O ) B b - t h e ~ i n i t i a l ~ C 3 ~ c o n v e r t a s e , ~}$ MASP-1, 2- mannose associated serine proteases; C4bp- C4 binding protein.

\section{Introduction}

Yersinia enterocolitica, a causative agent of yersiniosis, is a widespread gram-negative rod, especially in pigs, cattle and horses as natural reservoirs of this bacterium (Bucher et al. 2008, Bancerz-Kisiel et al. 2014). According to EU summary report on zoonoses, zoonotic agents and food-borne outbreaks 2011 (2013) and Polish Chief Sanitary Inspectorate, yersiniosis is the fourth most common zoonosis in Europe and Poland. Yersiniosis is a multiform disease and its symptoms include enterocolitis, lymphadenitis, fever, abdominal pain, diarrhoea, which is often bloody, or even sepsis. A very common disorder reported in pigs is gastroenteritis, while abortion caused by $Y$. enterocolitica is reported in cattle (Kot et al. 2010). Infections in animals including cattle and horses are often asymptomatic or may occur as sepsis associated with purulent changes in internal organs or as acute or chronic diarrhoea. Infections in animals may also appear as lymphadenitis or enteritis (Kot 2006). Due to multiform symptoms of yersiniosis in animals and humans, it is difficult to diagnose this disease (Bancerz-Kisiel et al. 2012). Cattle and horses as a possible reservoir of $Y$. enterocolitica less often than pigs suffer from yersiniosis and its course is usually mild, with no obvious clinical symptoms (Bucher et al. 2008). However, it is significant for the knowledge of the pathogenesis of $Y$. enterocolitica and of non-specific immune mechanisms associated with the disease in these animals to evaluate the bactericidal activity of serum depending on bacterial extracellular structures and the mechanisms of complement activation. The aim of the present study was to confirm the role of virulence factors of $Y$. enterocolitica in bovine and horse serum and also to investigate the mechanisms of animal complement activation against the $Y$. enterocolitica O:9 strain lacking the YadA and Ail proteins in the OM. In previous studies (Skorek et al. 2013), we have observed the role of Ail, YadA and OmpC proteins in conferring complement resistance in NHS. Moreover, since it is known that OmpC in Escherich a coli is the major antigen recognized by antibodies and C1q from human serum (Liu and Yan 2012), we would like to elucidate the significance of the OmpC in conferring animal complement resistance within another genus in the family of Enterobacteriaceae. 
Complement is a non-specific defence mechanism and the first line of defence in the fight against pathogens. Its basic functions are: complement the role of antibodies, support the process of opsonization and inflammation by attracting monocytes and neutrophils to the site of infection and degrade the cell membrane of the infecting microorganism (Ricklin et al. 2010). Despite the reports of strong interactions between proteins from three different routes of complement activation, the division of the pathway into classical, lectin, and alternative is still applied (Ricklin et al. 2010) (Fig. 1). The O-specific LPS (lipopolysaccharide) part activates the complement system by the classical route. Ra-Rd mutants in bacteria, which are defective in the biosynthesis of the O-specific chain or mutants defective in the biosynthesis of a complete core in LPS, activate the complement through the alternative pathway (Różalski 1995, Taylor 1995). Skurnik et al. (2007) suggest that LPS in the Y. enterocolitica O:9 serotype plays a role in assisting and strengthening the mainly YadA-dependent resistance to human complement action. Their results confirmed higher survival rate of the strains lacking the $\mathrm{O}$-antigen in human serum with the inhibited classical route, which suggests that the O-antigen of the $Y$. enterocolitica O:9 serotype activates the antibody-dependent pathways of human complement (Skurnik et al. 2007). In contrast, the lectin complement pathway is activated upon MBL (mannose-binding protein) binding to the sugar components on the pathogen surface.

A characteristic virulence factor for $Y$. enterocolitica is obviously YadA, encoded on the virulence plasmid $\mathrm{pYV}$ and expressed at $37^{\circ} \mathrm{C}$. YadA is a „multifaced” protein, the main adhesin and serum resistance factor. In the host body, adhesin YadA binds to the intestinal mucosa, collagen, laminin, fibronectin, human complement factor $\mathrm{H}$ and the complement regulator C4-binding protein (C4bp) (Tahir and Skurnik 2001) (Fig. 1). Factor H linked with YadA promotes the dissociation of $\mathrm{C} 3$ convertase, prevents its formation and acts as a cofactor for factor I degrading the $\mathrm{C} 3 \mathrm{~b}$ component to the inactivated form of $\mathrm{iC} 3 \mathrm{~b}$. The activation of factor $\mathrm{H}$ through YadA protects bacterial cells against complement activation via the alternative route. YadA binds to C4bp naturally promoting cleavage of the C4b2b complex (Ricklin et al. 2010). Thanks to this, fewer C3b and C9 (C5b-9) complement components are deposited on the outer membrane (OM) exposing adhesin YadA (Fig. 1) (Pilz et al. 1992). YadA binding to $\mathrm{C} 4 \mathrm{bp}$ prevents complement activation by the classical and the lectin pathway (Kirjavainen et al. 2008).

Another chromosomally encoded and expressed at $37^{\circ} \mathrm{C}$ virulence factor is the adhesive and invasive protein Ail. This protein facilitates binding and invasion of epithelial cells by $Y$. enterocolitica, and protects bacterial cells from the bactericidal activity of the complement through binding to factor $\mathrm{H}$ and $\mathrm{C} 4 \mathrm{bp}$, but to a lesser extent than YadA adhesin. This is because the O-antigen, a component of LPS, masks the Ail on the outer membrane (Leo and Skurnik 2011).

$\mathrm{OmpC}$ is a general diffusion porin and a non-specific channel for soluble, low molecular weight compounds conferring permeability properties to the outer membrane. The lack of OmpC in Y. enterocolitica O:9 (Ye9) confers resistance to $\beta$-lactam antibiotics (Brzostek and Hrebenda 1988). The OmpC porin in E. coli is the major antigen that activates human complement by the classical pathway and protects cells against serum bactericidal activity (Liu et al. 2012). Recent studies have shown that the mutant Ye9 lacking OmpC has a very low survival rate in conditions of incubation with human serum. It proves that $\mathrm{OmpC}$ exhibited in the $\mathrm{OM}$ is an element of protection against the bactericidal activity of serum (Skorek et al. 2013).

LPS is another significant factor in the pathogenesis of $Y$. enterocolitica. The biosynthesis of LPS in Yersinia spp. is strongly temperature-dependent. At $25^{\circ} \mathrm{C}$, LPS from $Y$. enterocolitica O:9 (Ye9) is known as semi-rough, while at $37^{\circ} \mathrm{C}$ the length of the $\mathrm{O}$-specific chain becomes shorter and LPS represents a rough type (Brzostek 2004, Skorek et al. 2013). The O-specific chain of the $Y$. enterocolitica serotype O:9 is a homopolymer of $N$-formyl perosamine (4,6-dideoxy-4-formamido-D-mannopyranose) (Holst 2003). It seems that $Y$. enterocolitica LPS molecules are probably able to activate the bactericidal mechanisms of both human and animal sera due to their structure.

\section{Materials and Methods}

\section{Bacterial strains and growth conditions}

The study was carried out on the Ye9 strain of $Y$. enterocolitica O:9 biogroup 2 and its isogenic mutants with different outer membrane proteins content. The mutants of $Y$. enterocolitica Ye9 lack protein Ail (Ye12), porin OmpC (OP3) and adhesin YadA (Ye9c) (Table 1). The strains of $Y$. enterocolitica Ye9 differing in outer membrane protein profile were constructed by Brzostek research group and previously described (Skorek et al. 2013). In this study bacteria were routinely cultivated in the liquid or solid medium Luria Bertani, LB (Sigma-Aldrich) under aerobic conditions at $25^{\circ} \mathrm{C}$ or $37^{\circ} \mathrm{C}$. 
Table 1. Yersinia enterocolitica O:9 strains used in this study.

\begin{tabular}{ccc}
\hline Strain no. & Characteristic of Y. enterocolitica O:9 & Source \\
\hline Ye9 (wt) & Wild type of Y. enterocolitica O:9 serotype, expressing YadA, OmpC, Ail & Department \\
Ye12 (Ye9 Ail-) & Ye9 lacking protein Ail & of Applied Microbiology, \\
OP3 (Ye9 OmpC-) & Ye9 lacking porin OmpC & University of Warsaw \\
Ye9c (Ye9 YadA-) & Ye9 lacking protein YadA & \\
\hline
\end{tabular}

\section{Normal bovine serum and normal horse serum}

The blood was purchased as a diagnostic product from the Pro Animali (Wroclaw). The blood and normal bovine serum (NBS) were obtained from five healthy animals, which were not receiving any antimicrobial drug treatment. The blood samples were taken from marked individuals no more than once a month. The cows were of the Polish „Holstein-Friesian” breed (HF breed). The herd has been maintained for many years on a dairy farm in the Wroclaw district and contains ca. 400 animals. The normal horse serum (NHrS) was obtained from the blood of a population of 7 horses: 5 Silesian breed horses and 2 Wielkopolska area breed horses. For the study, we used two pools of serum obtained twice at an interval of three months. The animals are under the care of a veterinarian, dewormed regularly. To obtain the average number of complement proteins from the healthy animals, each serum sample was mixed in a pool. NBS and $\mathrm{NHrS}$ were obtained from blood after 1- hour incubation at $37^{\circ} \mathrm{C}$ and followed by coagulation for 24 hours at $4^{\circ} \mathrm{C}$. Subsequently, the serum was separated from the clot and centrifuged $\left(3000 \mathrm{rpm}, 15 \mathrm{~min} ., 2^{\circ} \mathrm{C}\right)$. After centrifugation, the serum was collected, pooled and kept frozen at $-70^{\circ} \mathrm{C}$ in $0.5 \mathrm{~mL}$ portions. Each volume of serum, stored no longer than 3 months, was used only once and thawed immediately before being used. Sterility of the serum was previously checked. We plated and incubated each serum on solid LB (Sigma-Aldrich) at $25^{\circ} \mathrm{C}$ and $37^{\circ} \mathrm{C}$ for 48 and 24 hours respectively.

\section{NBS and NHrS bactericidal assay}

The bactericidal activity of 50\% NBS and 50\% $\mathrm{NHrS}$ was examined as described previously (Bugla-Płoskońska et al. 2010a) with slight modifications (Skorek et al. 2013). The percentage of serum was determined in previous experiments (data not published). Three $\mathrm{mL}$ of $\mathrm{LB}$ broth was inoculated to an overnight culture of a selected $Y$. enterocolitica strain. After overnight incubation at $37^{\circ} \mathrm{C}$, the culture was refreshed into $5 \mathrm{~mL}$ of $\mathrm{LB}$ to an $\mathrm{OD}_{600}$ of 0.5 . The incubation was finished when the bacterial culture achieved an $\mathrm{OD}_{600}$ of 1.2 and then bacterial cells were collected by centrifugation $\left(4000 \mathrm{rpm}, 20 \mathrm{~min}\right.$ at $\left.4^{\circ} \mathrm{C}\right)$. After centrifugation, the pellet was resuspended in $3 \mathrm{~mL}$ of physiological saline, $0.9 \%$ of $\mathrm{NaCl}(\mathrm{POCH})$. After mixing, $1 \mathrm{~mL}$ of the bacterial culture was diluted to achieve $\mathrm{CFU} / \mathrm{mL}$ (colony-forming units per mililiter), which is approximately equal to $10^{5}-10^{6}$. The prepared bacterial culture was mixed with NBS and NHrS or heat-inactivated serum in a ratio of 1:1. The mixtures were incubated at $37^{\circ} \mathrm{C}$ with shaking at $200 \mathrm{rpm}$ for $0,15,30$ and $60 \mathrm{~min}$. After the appropriate period of time, the dilutions were plated onto LB agar plates and incubated at $25^{\circ} \mathrm{C}$ for 48 hours. The average number of $\mathrm{CFU} / \mathrm{mL}$ was counted after incubation time. The mean value of $\mathrm{CFU} / \mathrm{mL}$ at time $0\left(\mathrm{~T}_{0}\right)$ was taken as $100 \%$ of the population directly mixed with the serum. The numbers of $\mathrm{CFU} / \mathrm{mL}$ were normalized to the $\mathrm{T}_{0}$ values as a percentage and then converted to $\log 10$ to show the survival rate of the bacteria in NBS and NHrS. The strains with survival rates of $>50 \%$ were considered resistant, the strains with survival rate of $<50 \%$ were considered susceptible to the bactericidal action of NBS or NHrS.

\section{Treatment of serum}

Blocking the alternative pathway of complement activation was carried out according to the methodology of Edinger et al. (1977). To block the alternative pathway of complement activation, the samples of NBS and $\mathrm{NHrS}$ were incubated at $50^{\circ} \mathrm{C}$ for $20 \mathrm{~min}$, which lead to the inactivation of factor B (Edinger et al. 1977). The classical and lectin pathways of complement activation were inhibited by the chelation of $\mathrm{Ca}^{2+}$ cations and addition of $\mathrm{Mg}^{2+}$ ions to the sample. Each 0.5 $\mathrm{mL}$ portion of serum was supplemented with: $50 \mu \mathrm{L}$ of $0.9 \% \mathrm{NaCl}(\mathrm{POCH}), 25 \mu \mathrm{L}$ of $200 \mathrm{mM} \mathrm{MgCl} 2 \times 6 \mathrm{H}_{2} \mathrm{O}$ (POCH) and $25 \mu \mathrm{L}$ of $200 \mathrm{mM}$ EGTA (Sigma-Aldrich) (Fine et al. 1972).

\section{Thermal inactivation of NBS and NHrS}

Serum inactivation was achieved by incubation at $56^{\circ} \mathrm{C}$ for $30 \mathrm{~min}$. The aim of this treatment was to confirm that complement is responsible for the bac- 
tericidal action of NBS and NHrS (Jankowski et al. 1996).

\section{Statistical analyses}

The numbers of $\mathrm{CFU} / \mathrm{mL}$ from the bactericidal assays were converted to percentage survival values, where the starting inoculum at $\mathrm{T}_{0}$ was set at $100 \%$, and values for the survival rates were expressed as $\log 10 \%$ CFU/mL (Bugla-Płoskońska et al. 2010b, Skorek et al. 2013). The data from each assay were compared by the analysis of ANOVA/MANOVA. Analyses of variance were used to determine the significant difference in bacteria survival following incubation for 15,30 and 60 min at $37^{\circ} \mathrm{C}$ in the presence of $50 \%$ NBS and $50 \%$ $\mathrm{NHrS}$. The differences in survival in two types of sera and the type of complement activation among bacterial strains of Ye9 (wt), Ye12 (Ye9 Ail'), OP3 (Ye9 $\mathrm{OmpC}^{-}$) and $\mathrm{Ye} 9 \mathrm{c}\left(\mathrm{Ye} 9 \mathrm{YadA}^{-}\right)$were also compared by multiple analyses of variance. The significant differences of bacterial survival rates were determined by the Tukey's comparison post-test. The p-values from these tests are shown in the text and the figures. $p<0.05$ indicates that the compared values are significantly different at a $95 \%$ confidence level.

\section{Results}

\section{Bactericidal activity of NBS against Y. enterocolitica strains}

The present study attempted to determine the level of sensitivity of $Y$. enterocolitica O:9 strains with different outer membrane protein content to the action of complement cascade. Moreover, the aim of this study was to analyse the correlation between the antigenic structure of the outer membrane of $Y$. enterocolitica O:9 strains and sensitivity to the bactericidal action of bovine and horse complement.

The strain Ye9 displayed resistance to killing by 50\% NBS (exhibited $78.79 \%$ survival after 60 -min. incubation) (Fig. 2). This wild type of $Y$. enterocolitica was more resistant to the NBS than its mutants lacking virulence factors such as Ail, YadA or OmpC, whose survival rate decreased significantly after 60 -min incubation with $50 \%$ NBS ( $<<0.0001$, Fig. 2). Strains Ye9 lacking protein, Ail, OmpC or YadA in the OM were sensitive to the bactericidal action of 50\% NBS (Fig. 2). Survival values of strains Ye12, OP3 or Ye9c after 60-min incubation with complement of 50\% NBS were $17.13 \%, 0.94 \%$ and $38.85 \%$ respectively (Fig. 2). However, the mutant Ye9c lacking YadA showed higher resistance to killing by 50\% NBS only after 15 and 30-min incubation as compared to the wild type of Ye9 (p<0.02) (Fig. 2). The survival rate of the Ye9c strain was 4 and 3-fold higher than the survival rate of the Ye9 wild type, after respectively 15 and 30-min incubation in NBS. These results proved that the constructs of the wild type of the $Y$. enterocolitica strain lacking one of the OMPs became more sensitive to the bactericidal action of NBS in comparison with the wild type of the Ye9 strain.

The strain Ye9 displayed resistance to killing by $50 \%$ NHrS (exhibited $166.78 \%$ survival after 60 -min incubation). This survival value is much higher than the survival rate of the wild type strain (Ye9) in 50\% NBS. The bactericidal action of $50 \% \mathrm{NHrS}$ against the Ye9 mutants was also observed after 60-min incubation $(\mathrm{p}<0.0005)$. The survival rate of the Ye12 strain (Ye9 Ail'), the OP3 strain (Ye9 OmpC) and the Ye9c strain (Ye9 YadA'), significantly decreased after 60-min incubation with $\mathrm{NHrS}$ and their survival values reached $21.95 \%, 1.83 \%$ and $49.73 \%$ respectively (Fig. 3 ).

The Ye12 strain lacking Ail showed moderate sensitivity to the bactericidal action of both normal sera. However, its viability in 50\% NBS and 50\% NHrS was relatively lower than the survival of Ye9 (wt) and Ye9c with lacking YadA $(\mathrm{p}<0.001)$ (Fig. 2, 3). The OP3 strain (Ye9 OmpC) was the most sensitive to the bactericidal activity of $50 \% \mathrm{NBS}$ and $50 \% \mathrm{NHrS}$ as compared to the sensitivity level of other Ye9 strains $(p<0.001)$. The viability of the OP3 strain was significantly decreased upon incubation with both types of sera, particularly after 60 -min incubation. Its survival rate decreased 117- and 55-fold after 60-min incubation in 50\% NBS and 50\% NHrS respectively $(\mathrm{p}<0.0001)$ (Fig. 2, 3). The results suggest that virulence proteins such as Ail, OmpC and YadA can play a significant role in protecting bacterial cells against the horse and bovine serum action.

\section{Mechanisms of complement activation of $Y$. enterocolitica strains in NBS and NHrS}

In the next stage of this study, it was decided to investigate which mechanisms of complement activation are responsible for the lysis of bacterial cells of Ye9 with a different profile of the outer membrane proteins. In the bactericidal assay of 50\% NBS it was demonstrated that serum-sensitive strains Ye12 lacking Ail and Ye9c lacking YadA were killed by bovine complement when the alternative pathway in the serum had been inhibited (Fig. 4). The survival of all Y. enterocolitica strains was significantly reduced in the classical/lectin pathway of NBS while their survival in the alternative pathway of NBS was noticeably higher $(\mathrm{p}<0.005)$ (Fig. 4). This result could indicate the crucial role of classical/lectin pathways in complement activation and bactericidal properties of NBS. 


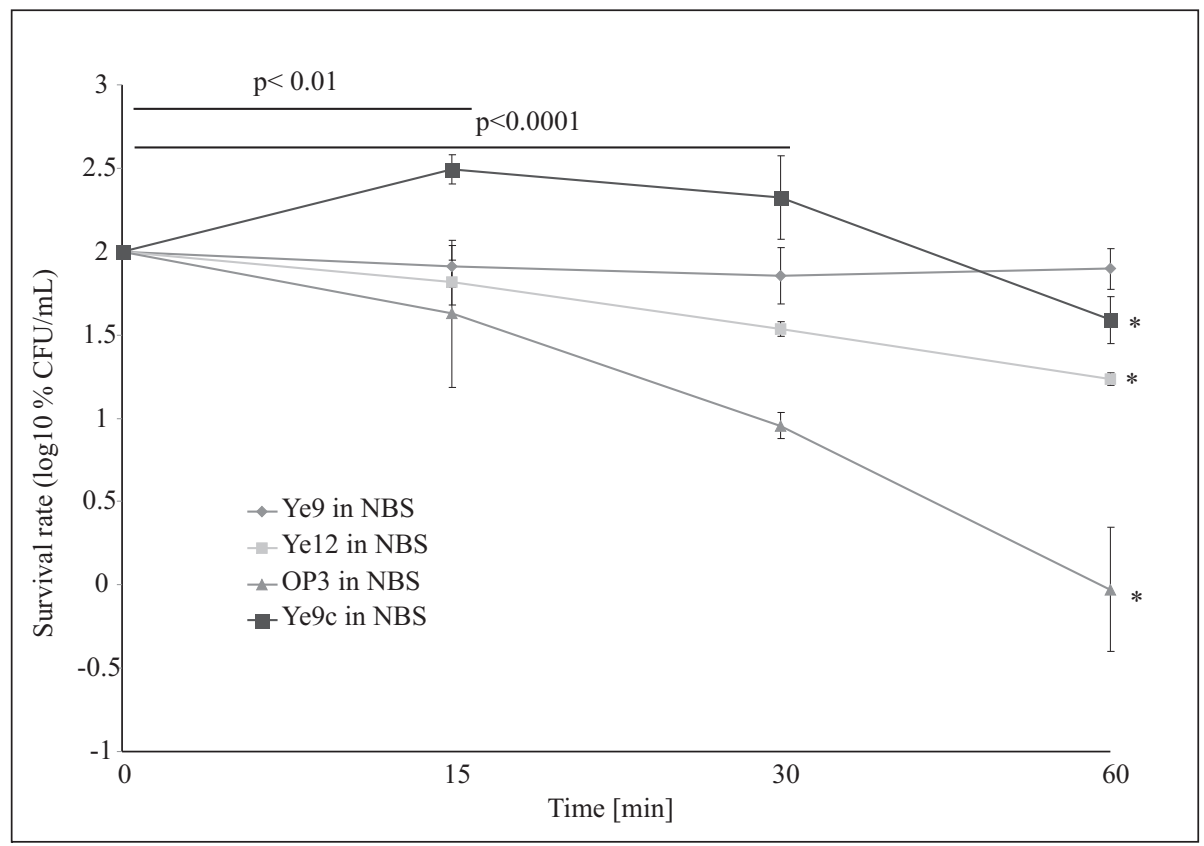

Fig. 2. The bactericidal activity of NBS against $Y$. enterocolitica $\mathrm{O}: 9$ strains. The numbers of $\mathrm{CFU} / \mathrm{mL}$ were normalized to the $\mathrm{T}_{0}$ values as a percentage and then converted to $\log _{10}$ to show the survival rate of the bacteria in NBS. The number of $\mathrm{CFU} / \mathrm{mL}$ at $\mathrm{T}_{0}$ was considered as $100 \%$ survival. Data are the means $\pm \mathrm{SD}$ from four independent experiments. The survival rate of Ye9 (wt), Ye12 (Ye9 Ail ${ }^{-}$), OP3 (Ye9 OmpC-) Ye9c (Ye9 YadA') strains in 50\% NBS after 15, 30, and 60-min. incubation at 37 ${ }^{\circ} \mathrm{C}$. The asterisks indicate statistically significant differences between bacterial strains $\left({ }^{*} \mathrm{p}<0.0001\right.$, by one-way repeated measures ANOVA with the Tukey's comparison post-test).

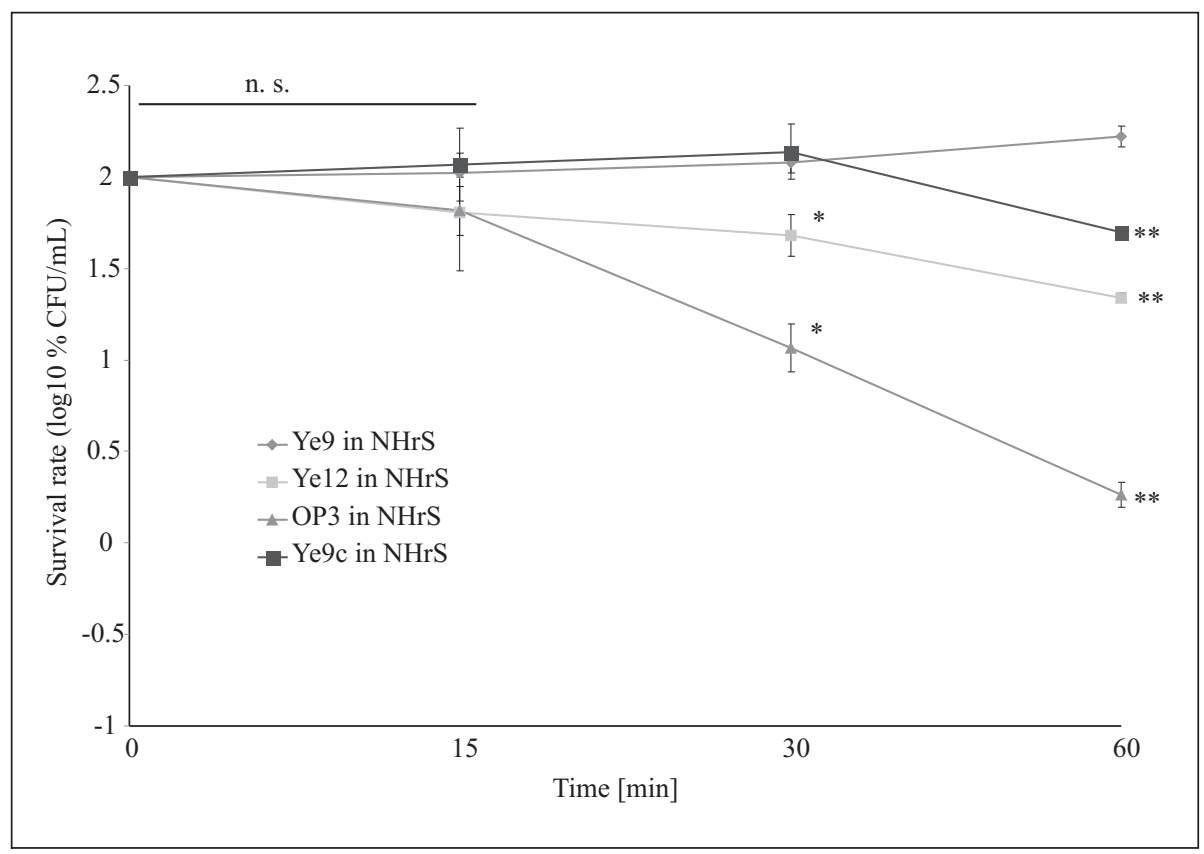

Fig. 3. The bactericidal activity of NHrS against $Y$. enterocolitica $\mathrm{O}: 9$ strains. The numbers of $\mathrm{CFU} / \mathrm{mL}$ were normalized to the $\mathrm{T}_{0}$ values as a percentage and then converted to $\log _{10}$ to show the survival rate of the bacteria in NHrS. The number of CFU $/ \mathrm{mL}$ at $\mathrm{T}_{0}$ was considered as $100 \%$ survival. Data are the means \pm SD from three independent experiments. The survival rate of Ye9 (wt), Ye12 (Ye9 Ail'), OP3 (Ye9 OmpC') Ye9c (Ye9 YadA') strains in 50\% NHrS after 15, 30, and 60-min. incubation at 37 ${ }^{\circ} \mathrm{C}$. The asterisks indicate statistically significant differences between bacterial strains $\left({ }^{*} \mathrm{p}<0.001,{ }^{*} \mathrm{p}<0.0005\right.$, by one-way repeated measures ANOVA with the Tukey's comparison post-test), n.s. not significant ( $>0.05)$. 


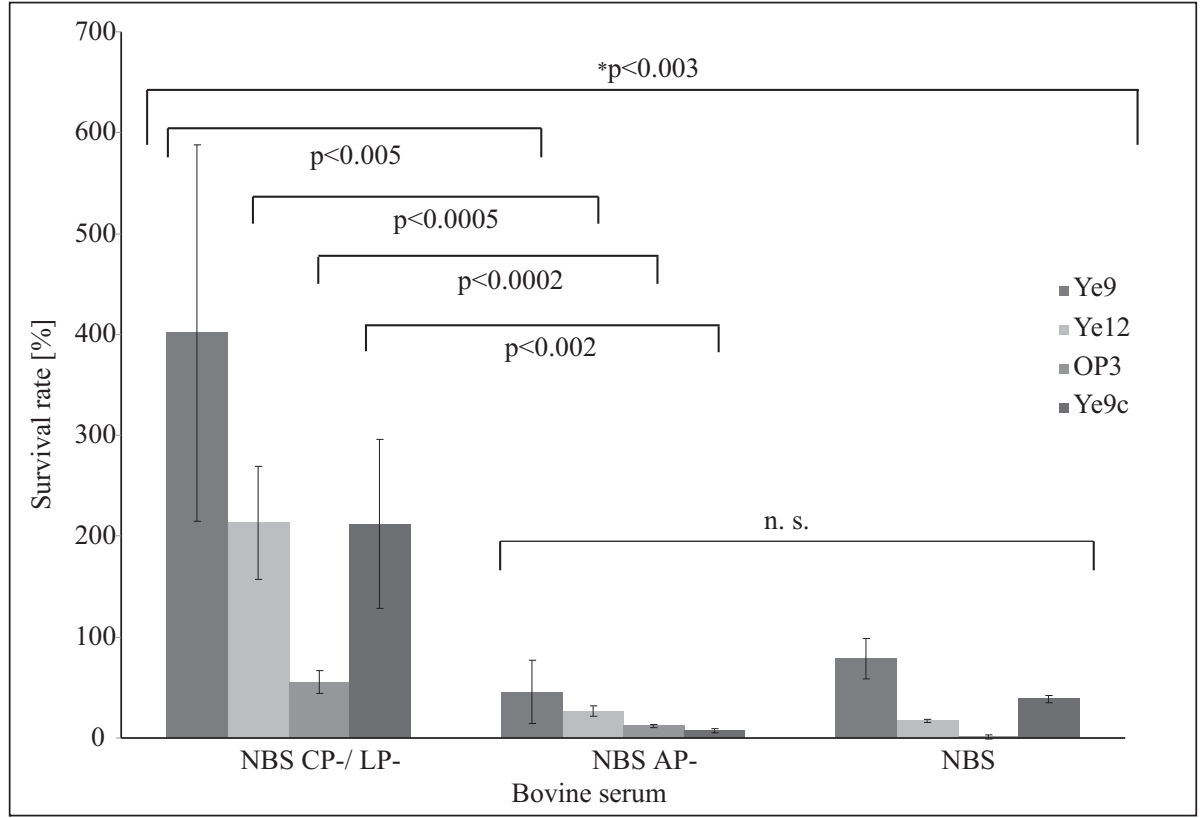

Fig. 4. Bactericidal activity of NBS CP-/LP-, NBS AP-, and NBS against $Y$. enterocolitica O:9 strains. NBS AP-: bovine serum with the inhibited alternative pathway of complement activation, NBS CP-/LP-: bovine serum with the inhibited classical/lectin pathway of complement activation, NBS: normal bovine serum. The number of CFU/mL at $\mathrm{T}_{0}$ was considered as $100 \%$ survival. Data are the means \pm SD from at least three independent experiments. The asterisk indicates a statistically significant difference between the bacterial survival rate and the type of complement activation ( ${ }^{*} \mathrm{p}<0.003$, by analyses of ANOVA/MANOVA with the Tukey's comparison post-test). The classical/lectin pathway of complement activation in bovine serum significantly inhibited the growth of Ye9 strains compared to an alternative ones $(\mathrm{p}<0.005$, by one-way ANOVA with the Tukey's comparison post-test), n.s. not significant $(\mathrm{p}>0.05)$.

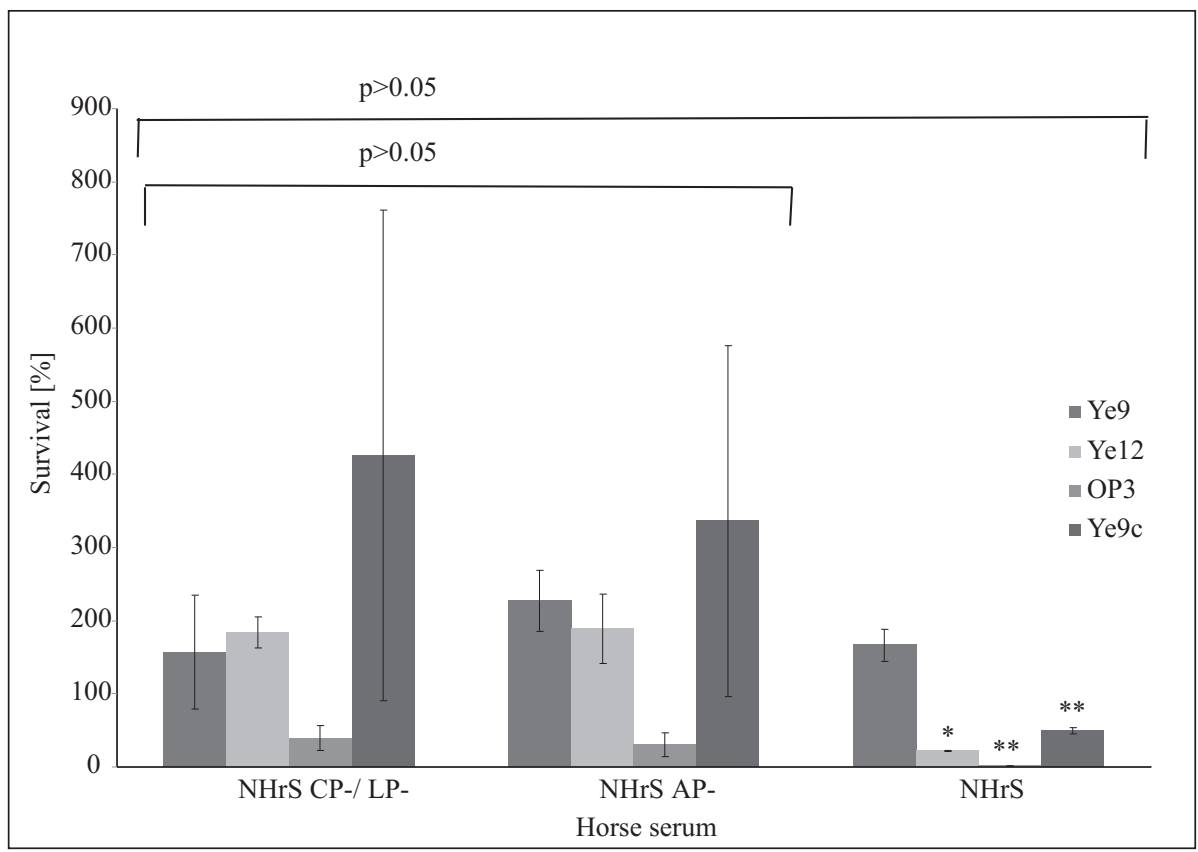

Fig. 5. Bactericidal activity of NHrS CP-/LP-, NHrS AP- and NHrS against $Y$. enterocolitica O:9 strains. NHrS AP-: horse serum with the inhibited alternative pathway of complement activation, NHrS CP-/LP-: horse serum with the inhibited classical/lectin pathway of complement activation, NHrS: normal horse serum. Data are the means \pm SD from at least three independent experiments. The asterisks indicate statistically significant differences in the bacterial survival of $Y$. enterocolitica strains in NHrS $\left({ }^{*} \mathrm{p}<0.001,{ }^{*} \mathrm{p}<0.05\right.$, by one-way ANOVA with the Tukey's comparison post-test). The differences between the bacterial survival rate and the type of complement activation were not significant ( $p>0.05$, by analyses of ANOVA/MANOVA with the Tukey's comparison post-test). 
The strains Ye12 and Ye9c were relatively more resistant to killing by a horse complement system in both types of complement pathways in $\mathrm{NHrS}$ as compared to the Ye9 (wt) strain. Despite this, the differences between their survival rate and the type of complement mechanism in NHrS were not statistically significant ( $p>0.05$, Fig. 5). On the basis of these results, it can be concluded that the activation of $\mathrm{NHrS}$ against the $\mathrm{Ye} 9 \mathrm{c}$ and Ye12 strains requires the parallel activation of the classical, lectin, and alternative pathways in the bactericidal activity.

In the bactericidal action of NBS or NHrS against $Y$. enterocolitica OP3 an independent activation of the classical, lectin, or alternative pathway was observed (Fig. 4, 5). Complements in NBS and NHrS were activated against bacterial cells independently of the OmpC presence in the OM. Presumably, the OmpC porin can protect bacterial cells against complement action. It could be confirmed by the high serum sensitivity of the OP3 strain to the activity of NBS and NHrS (Fig. 2, 3).

\section{Discussion}

$Y$. enterocolitica is a causative agent of yersiniosis, capable of avoiding host defence mechanisms and survival in the gastrointestinal tract, but it is also characterized by a tropism for lymphoid tissue and the ability to cause systemic infection (Brzostek 2004, Skorek et al. 2013). In this study, high complement resistance of the $Y$. enterocolitica O:9 wild type strain to NBS and NHrS was confirmed. Recent results (Skorek et al. 2013) showed moderate NHS resistance of the strain Ye9. A possible explanation for this phenomenon is the concentration of complement components. In human serum, complement titer is 100 units $/ \mathrm{mL}$, while in cattle it is 15 units $/ \mathrm{mL}$, and less than 10 units $/ \mathrm{mL}$ in horses (Grzybek-Hryncewicz 1967). On this basis, we could explain greater resistance of a strain of $Y$. enterocolitica O:9 to NHrS, whose physiological titer of complement is low. Another explanation of the present result is a rare occurrence of $Y$. enterocolitica in cows and horses compared to the general prevalence of the bacteria in pigs. Blood was obtained from healthy cattle and horses with no symptoms of yersiniosis, therefore the serum complies with a reference value according to Grzybek-Hryncewicz (1967). The possible effect of the rare occurrence of $Y$. enterocolitica in these animals may result in low levels of antibodies against these bacteria. The presence of $Y$. enterocolitica specific antibodies in the serum could potentially lead to coating the Ye9 bacteria and targeting them for phagocytosis by macrophages and neutrophils. Another antibody-dependent mechanism is the activation of the classical pathway of the complement system (Ricklin 2010). The high resistance of Ye9 strains to bactericidal action of animal serum could be associated with the absence of previously described effector mechanisms of humoral immunity.

The low values of the survival rate of strains Ye12, OP3 and Ye9c in NBS and NHrS have confirmed that proteins Ail, OmpC and YadA can play an essential role in ensuring complement resistance of $Y$. enterocolitica O:9. We demonstrated (Skorek et al. 2013) an effect of the bactericidal action of human complement against $Y$. enterocolitica that was very similar to the present study. Resistance of the Ye12 strain (Ail-) to the bactericidal action of NHS was 40-fold lower than that observed in the wild type of strain Ye9. In the case of the bactericidal action of NBS and NHrS against the Ye12 strain, resistance reached 4.6 and 8 -fold lower value as compared to the Ye9 strain. Resistance of the OP3 strain ( $\left.\mathrm{OmpC}^{-}\right)$to the bactericidal action of NHS was 20-fold lower in comparison with that observed in the wild type of Ye9 (Skorek et al 2013). Resistance of the OP3 strain to NBS and NHrS was respectively 84 and 91-fold lower than that observed in the Ye9 wild type strain. Values of the survival rate [\%] of $\mathrm{Ye} 9 \mathrm{c}\left(\mathrm{YadA}^{-}\right)$strains in NBS and NHrS were higher than expected. The previous study revealed that the survival rate of $\mathrm{Ye} 9 \mathrm{c}$ in NHS exhibited the lowest value (Skorek et al. 2013). It should be emphasized that the survival rate of Ye9c strain in NBS and NHrS substantially decreased only after 60-min incubation. Together, the results demonstrate the significance of Ail, OmpC or YadA in conferring the animal serum resistance. The differences in survival rates [\%] possibly lie in the concentration of complement components in various sera and the occurrence of $Y$. enterocolitica in cows and horses.

In this research it has been proved that the classical/lectin pathways are dominant mechanisms of complement activation in NBS. However, it may also be worthwhile to consider a hypothesis that the lectin pathway is the only factor that potentially activates NBS complement via the MBL protein binding to the sugar components of the surface structures. Perhaps the MBL protein binds to LPS $Y$. enterocolitica O:9 which is a homopolymer of $N$-formyl perosamine (4,6-dideoxy-4-formamido-D-mannopyranose) (Tahir and Skurnik 2001). The aforementioned perosamine is a mannose derivative, which could potentially activate the complement system by the lectin pathway. On the basis of this hypothesis, we found that $Y$. enterocolitica O:9 LPS can potentially contribute to complement activation. The shortened $\mathrm{O}$-specific chain at $37^{\circ} \mathrm{C}$ in $Y$. enterocolitica O:9 strains does not protect bacterial cells against the deposition of complement components on the OM. Additionally, LPS is composed of repeat- 
ing subunits consisting of a mannose derivative that could be a potential target for binding by MBL protein. This information provides another possible explanation why the classical/lectin pathways are the dominant mechanism of complement activation in NBS. However, due to the shortened length of the O-specific chain in LPS and, thus, a reduced amount of sugar components of the O-antigen, we expected weaker complement activation. It is possible that factors other than LPS, such as the OMPs are responsible for complement activation by the lectin pathway and then the lysis of bacterial cells.

\section{References}

Bancerz-Kisiel A, Szczerba-Turek A, Platt-Samoraj A, Szweda W (2012) Distribution of the $y m o A$ and $y s t A$ genes and enterotoxins Yst production by Yersinia enterocolitica strains isolated from humans and pigs. Pol J Vet Sci 15: 609-614.

Bancerz-Kisiel A, Szczerba-Turek A, Platt-Samoraj A, Socha P, Szweda W (2014) Bioserotypes and virulence markers of $Y$. enterocolitica strains isolated from roe deer (Capreolus capreolus) and red deer (Cervus elaphus). Pol J Vet Sci 17: 315-319.

Brzostek K (2004) Regulation of virulence factors in Yersinia enterocolitica. Post Microbiol 43: 7-38 (in Polish).

Brzostek K, Hrebenda J (1988) Outer-membrane permeability to beta-lactam antibiotics in Yersinia enterocolitica. J Gen Microbiol 134: 1535-1540.

Bucher M, Meyer C, Grotzbach B, Wacheck S, Stolle A, Fredriksson-Ahomaa M (2008) Epidemiological data on pathogenic Yersinia enterocolitica in Southern Germany during 2000-2006. Foodborne Pathog Dis 5: 273-280.

Bugla-Płoskonska G, Futoma-Kołoch B, Rybka J, Gamian A, Doroszkiewicz W (2010a) The role of complement activity in the sensitivity of Salmonella O48 strains with sialic acid-containing lipopolysaccharides to the bactericidal action of normal bovine serum. Pol J Vet Sci 13: 53-62.

Bugla-Płoskońska G, Rybka J, Futoma-Kołoch B, Cisowska A, Gamian A, Doroszkiewicz W (2010b) Sialic acid-containing lipopolysaccharides of Salmonella O48 strains - potential role in camouflage and susceptibility to the bactericidal effect of normal human serum. Microb Ecol 59: 601-613.

Edinger D, Bello E, Mates A (1977) The heterocytotoxicity of human serum. I. Acitvation of alternative complement pathway by heterologous target cell. Cell Immunol 29: $174-186$.

EFSA, (European Food Safety Authority), ECDC (European Centre for Disease Prevention and Control) (2013) The European Union Summary Report on Trends and Sources of Zoonoses, Zoonotic Agents and Food-borne Outbreaks in 2011. EFSA Journal 11: 3129-3379.

El Tahir Y, Skurnik M (2001) YadA, the multifaceted Yersinia adhesin. Int J Med Microbiol 291: 209-218.
Fine DP, Marney SR Jr, Colley DG, Sergent JS, Des Prez RM (1972) C3 shunt activation in human serum chelated with EGTA. J Immunol 109: 807-809.

Grzybek-Hryncewicz K (1967) Complement, its role in phagocytosis phenomenon. Post Hig Med Dosw 21: 611-740 (in Polish).

Holst O (2003) Lipopolisaccharides of Yersinia. An overview. Adv Exp Med Biol 529: 219-228.

Jankowski S, Cisowska A, Doroszkiewicz W (1996) Influence of ozone on the susceptibility of Escherichia coli K1 to the bactericidal action of serum. Folia Microbiol (Praha) 41: 395-400.

Kirjavainen V, Jarva H, Biedzka-Sarek M, Blom AM, Skurnik M, Meri S (2008) Yersinia enterocolitica serum resistance proteins YadA and ail bind the complement regulator C4b-binding protein. PloS Pathog 4: e1000140.

Kot B (2006) Phenotypic and genotypic characteristics of Yersinia enterocolitica rods and their meaning in detection of potentially pathogenic strains. University of Podlasie Publisher, Siedlce (in Polish).

Kot B, Piechota M, Jakubczak A (2010) Analysis of occurrence of virulence genes among Yersinia enterocolitica isolates belonging to different biotypes and serotypes. Pol J Vet Sci 13: 13-19.

Leo JC, Skurnik M (2011) Adhesins of human pathogens from the genus Yersinia. Adv Exp Med Biol 715: 1-15.

Liu YF, Yan JJ, Lei HY, Teng CH, Wang MC, Tseng CC, Wu JJ (2012) Loss of outer membrane protein $\mathrm{C}$ in $E s$ cherichia coli contributes to both antibiotic resistance and escaping antibody-dependent bactericidal activity. Infect Immun 80: 1815-1822.

Pilz D, Vocke T, Heesemann J, Brade V (1992) Mechanism of YadA-mediated serum resistance of Yersinia enterocolitica serotype O3. Infect Immun 60: 189-195.

Ricklin D, Hajishengallis G, Yang K, Lambris JD (2010) Complement: a key system for immune surveillance and homeostasis. Nat Immunol 11: 785-797.

Różalski A (1995) Lipopolysaccharide of Gram-negative bacteria - chemical structure, biological activity and significance in the pathogenicity. I. Chemical structure and physico-chemical properties of lipopolysaccharides. Post Mikrobiol 34: 289-313 (in Polish).

Skorek K, Raczkowska A, Dudek B, Miętka K, Guz-Regner K, Pawlak A, Klausa E, Bugla-Płoskońska G, Brzostek $\mathrm{K}$ (2013) Regulatory protein OmpR influences the serum resistance of Yersinia enterocolitica O:9 by modifying the structure of the outer membrane. PloS One 8: e79525.

Skurnik M, Biedzka-Sarek M, Lubeck PS, Blom T, Bengoechea JA, Perez-Gutierrez C, Ahrens P, Hoorfar $J$ (2007) Characterization and biological role of the O-polysaccharide gene cluster of Yersinia enterocolitica serotype O:9. J Bacteriol 189: 7244-7253.

Taylor PW (1995) Resistance of bacteria to complement. In: Roth JA, Bolin CA, Brogden KA, Minion C, Wannemueller MJ (eds) Virulence of bacterial pathogens. 2nd ed., American Society for Microbiology, Washington DC, pp 49-64. 